\title{
Reflecting on Social Identities in Teacher Education
}

\author{
Margaret Wells \\ Ontario Institute for Studies in Education, University of Toronto
}

\begin{abstract}
This paper explores the author's experience in supporting teacher candidates to consider how their social locations affect their teaching. Pedagogical strategies to examine social identities are described and teacher candidates, responses to these strategies are examined critically within the broader context of pursuing social justice and equity within schools.
\end{abstract}

\section{Introduction}

How do we encourage people who are becoming teachers to consider the impact of their social locations on their teaching? The context for this paper is teaching a foundations course, School and Society, within the Initial Teacher Education Program at the Ontario Institute for Studies in Education at the University of Toronto. Traditionally, this course has been seen as a major opportunity within the program-but hopefully, not the only one-for teacher candidates to become aware of the systemic obstacles to social justice and equity within schools. All of the specific references to teacher candidates in this paper come from the class that I taught in the fall of 2014 (these teacher candidates have all given explicit permission to include quotations from their responses). These teacher candidates, though all from diverse disciplines and as a result having different teaching subjects, were all preparing to teach in secondary schools.

In my twelve years of teaching this course, it has become increasingly clear that this means supporting teacher candidates in thinking through how their own social locations in terms of the multiple and intersecting aspects of their identities (e.g. gender, race, ethnicity, socioeconomic class, sexual identity, abilities/disabilities and so on) impact their work as teachers. My hope is that as the teacher candidates become more critically aware of their own social identities, they will develop an understanding of how the social identities of their students play a significant role in their academic and social success within existing school systems. Additionally, I hope that the teacher candidates consider the kinds of educational and societal changes that will promote social justice and equity within schooling.

This course is based on the assumption that schools are social and political institutions situated in historical time. Schools are shaped by the particular society in which they develop and in turn play a role in shaping that society. A second assumption is that knowledge, identities, and relationships are socially constructed and that schooling plays an important role in these constructions.

Through readings, small and large group discussions, and experiential activities, teacher candidates examine what John Dewey referred to as "routine action" in schools that is, the takenfor-granted definition of everyday reality in which problems, goals, and the means for their solution become defined in particular ways [1]. The goal of the critical reflection in which we engage is not meant to be nihilistic but to be a hopeful activity that will focus on the obstacles to equity within systems of education and ways in which these obstacles can be confronted effectively. We focus on how teachers can support students to analyse power relationships within society critically and to develop the skills and knowledge to become active participants in society, particularly in working towards a socially just society.

In this course, I want the teacher candidates to understand through reflective experience how knowledge is socially constructed and how their social locations both allow and hinder how they might "know" other people, particularly their students. In the process of developing this critical awareness, I hope that the teacher candidates do not become mired in feelings of guilt, anger, or hopelessness that may occur 
when they examine their own social privileges and/or disadvantages. I encourage them to bring a "compassionate" approach to this selfexamination.

In our discussions of identity, we examine readings that challenge the idea of identity as an essential and fixed category and focuses instead on identity as a more "elusive" process that is "constructed and open-ended." Dan Yon's notion of diasporic identities as "being at home in the place where one lives while still living with the memories and shared histories of the place from which one or one's ancestors have come" is very relevant for my teacher candidates and for the students who they will teach [2]. In fact, schools in many regions of the Greater Toronto Area are the prime exemplars of diasporic spaces since so many of our elementary and secondary students are first or second generation Canadians. Both my teacher education classes and the students who they work within their practice teaching illustrate the multicultural reality of Toronto schools. However, the demographic description of the regular teachers in the schools is quite different. In most cases, teacher candidates are working with mentors who are predominantly of European heritage.

Another important consideration in any discussion of social identities is the understanding of intersectionality, that is the idea that the various aspects of our identities exist simultaneously within us. Although we may at times hold up one aspect of identity for discussion, we cannot truly separate out these various strands of how we are seen and how we see ourselves.

Given my emphasis on teacher candidates being aware of their own social identity and how it might shape their perceptions, it is incumbent on me to describe my own social identity. I identify as a white female of Irish heritage who comes from a lower-middle class family background but is now clearly middle class. I am keenly aware of class issues, probably stemming from my experience attending a secondary school outside my neighborhood that had some students who shared my class background but where the majority of the students were from upper middle class and even upper class backgrounds. I also identify as heterosexual and given my age am very aware of how my understanding of sexual identity as an important marker has come to me as an adult and was not something that I considered throughout my early education including my undergraduate education. I am able-bodied and was never labeled as a student who learned differently from the norm. Again, I am conscious of how this identity marker is probably the one that I have been least aware of in my own life. As a teacher, I quickly realized how regular schooling was disadvantaging so many students. In the first school where I taught most of the students were first generation predominantly European immigrants who were streamed into lower level of ability courses. I saw that the fact that many were still acquiring full academic English language proficiency and came from working class families who were unfamiliar with the Ontario school system had resulted in them being placed in "dead end" programs of study. I became interested in alternative educational programs within the school system and got involved with a group of teachers focused on creating an alternative school catering to the needs of poor and working class students. That school still exists within the Toronto District School Board. My teaching philosophy resonates with Nel Noddings ideas on how central an ethic of care should be in teaching. This ethic of care "embodies a relational view of caring...(in which) both carer and cared-for contribute to this relation" [3].

Prior to the first class meeting I ask the teacher candidates to read a short excerpt entitled, "How to Engage Constructively in Courses that Take a Critical Social Justice Approach" from the text Is Everyone Really Equal? An Introduction to Key Concepts in Social Justice Education by Özlem Sensoy and Robin DiAngelo. In the section that I give the teacher candidates, the authors lay out five principles to consider when taking courses focused on social justice [4]. The first time that I contemplated giving this excerpt I was somewhat hesitant because while I felt that these principles were important to consider, I also felt that the tone of the excerpt was somewhat "preachy" and demeaning and I wondered if this was the first impression of the course that I wanted to provide. My sense of the importance of the principles (striving for intellectual humility, realizing that opinions are not the same as informed knowledge, letting go of anecdotal 
evidence in order to examine patterns, using one's reactions as entry points for gaining deeper self-knowledge, recognizing how one's positionality informs one's responses) in the end outweighed any concerns about the tone of the text and the first impressions that this might make.

\section{Teaching Strategies and Teacher Candidate Responses}

At our first meeting, I ask the teacher candidates to consider how their families and their communities (however they might define both these terms) have influenced their social identity. In the whole group feedback on this activity, we discuss how the way we define ourselves affects how others see us and how others' perceptions affect the way we define ourselves. These perceptions in turn affect the relationships we have in society. Finally, I ask the teacher candidates to consider the constancy or fluidity of their concepts of identity, for example, how these might change over time and in various contexts.

One of the first activities that I do with teacher candidates is to post the following aspects of social identity on large pieces of paper around the walls of the classroom: gender, race, socioeconomic class, sexual orientation, immigration status, religion, ability/disability. This activity suggested to me by a colleague uses the categories around which the Ontario Human Right Commission (this provincial organization develops public policy on human rights and conducts public inquiries into human rights violations) receives the most complaints. I then ask them to move to one of the identity markers that best represents the aspect of their identity that they are most conscious of on a day-to-day basis. Once there they discuss why they chose that aspect and do a short sharing with the whole group. This process is repeated as I ask them to move to the aspect of their identity that they are least conscious of on a day-to-day basis and then finally an aspect of their identity that affords them the most privilege in our society.

In doing this activity I am opening the doors for some teacher candidates to begin considering their own social identities. For some who have backgrounds in sociology, women's studies, and/or equity studies this is not new material but for many it is. Many teachers both in the secondary classroom and in university courses dealing with such topics may use similar strategies. One of my teacher candidates recently wrote about being a student in a secondary classroom where a teacher was using a privilege line on which people moved back or forward depending on their response to various questions. This teacher candidate describes her response:

"As a white, straight, middle class female I was relatively close to the high point end, felt guilty about it, and had trouble seeing the intention of this activity. My teacher was trying to convey how society labels and discriminates but how was this working toward solving the issue?"

This is the type of response that I want to make sure is avoided or at least processed. In saying this, I am not faulting the secondary teacher; all educators are aware that they may do certain activities that are taken up by their students quite differently than the teacher may have intended. I am simply saying that strong reactions such as that of this teacher candidate need to be processed so that the students can consider why they had this response and can continue being engaged in this important learning.

What I hope is that while the emotional response is acknowledged and explored, the teacher candidate can remain with the ongoing conversation about identities in a way that acknowledges that all must be involved in this work. A young white, male teacher candidate wrote the following after we had done some extended work on identities:

"Recently I've been made aware of the privilege I've been afforded as a result of my being white, but it's been difficult for me to pinpoint the precise nature of this privilege. I suppose that because it's been an inherent part of my life since birth I've been unable to recognize its impact. I'm led to believe that my advantage is essentially ubiquitous, and that my accomplishments are therefore (implicitly) devalued. I don't mean to come off as a smartass (sic), but this has been my reaction to this course thus far. I wouldn't say that I feel attacked, but I do find myself feeling defensive. I've never considered my 'race' before but I've been hyper aware of it for the past three weeks. I'm not sure what to do with these feelings but I think that 
confronting them is a major objective of the course."

I was heartened that this teacher candidate can write such a piece about the course work. He acknowledges feeling defensive but by the end of the piece also acknowledges his need to confront these feelings. His feelings are not simply the reason to reject what is being discussed but can be brought into the discussion for analysis. In his final paper, a critical analysis of his practicum experience, this teacher candidate spoke of his experience in the course as being "complicated." He felt that his own identity had been "consistently represented as the poster child for the oppressive hegemony" while many others in the class "had plenty of opportunity to identify themselves as victims of a tyrannical system" from which he himself derived only privileges. He felt that there was a dominant ideology in the class that could not be challenged, especially by someone who represented those with power in our society. Nevertheless, in this final paper he goes on to analyze his interactions with a student who he described as "a fourteen year old, ablebodied brown male." The teacher candidate had made assumptions that this boy was "exceptionally intelligent and mature" and had grouped him with other students who he felt would benefit from this boy's leadership. However, the teacher candidate became frustrated by the boy's disengagement from the group work and the fact that he sometimes used this time to complete homework from other courses. One day he publicly confronted the boy about this and the boy was upset by the assumptions that the teacher candidate was making about him and complained to the mentor teacher. When the teacher candidate heard about the boy's complaint, he apologized to him and the boy accepted his apology. The mentor teacher reassured the teacher candidate that the incident was not as significant as he felt it was and that he should let go of his feelings of regret. The teacher candidate wrote:

"I will never forget my mistake with Ali (fictional name). I can't say with certainty what exactly went wrong that day, but the process of reflection has helped me to identify some of the more significant factors at play. When I consider how to act upon these revelations, I find that my options are abstract and vague. I can try to be 'more aware' of my own biases, but what does that look like in practice? I can make an effort to take a more dispassionate approach to discipline, but how can one completely disengage from one's emotions? If nothing else, I am thankful to have had the experience of meaningful failure in the classroom. I have been humbled in a way that can only make me a better teacher."

When I read this teacher candidate's final paper, my own response was also very complicated. I was dismayed that he continued to feel that the course had made him feel that his identity had been portrayed so negatively and that as a result he felt that he could not really claim any of his accomplishments in life because they were simply the result of his privilege. I wanted to engage in further dialogue with this teacher candidate partly to reassure him that I did feel that he should be proud of his accomplishments. I was also concerned that he felt that he had been silenced by a "dominant ideology" in the class. Was there in fact such a presence in the class that served to close down discussion for those who disagreed? However, as I continued to read the paper, I was impressed by the teacher candidate's analysis of his own interactions with this student and wondered (perhaps to reassure myself) about whether he would have been so insightful before the course. I am conscious of my own contradictory response to this teacher candidate-my not wanting to have created a space in which he felt that his responses were written off but my simultaneous understanding that the course material and my approach to it would be an uncomfortable space for someone who may never before have had to consider his privilege.

Another strategy that I use with students early on in the course is the Flower Exercise, which was adapted by Barb Thomas from Enid Lee, Letters to Marcia: A Teacher's Guide to Anti-Racist Education [5].

By this point in the course we have had enough discussion and reading on social identities that we are very able to collectively generate the categories that we place on the various petals of the flower. While certain categories are always present each class has their own dynamic. For example, in one class the concept of us being people who live in the First World was important to many to add to our list of identity categories. Then we generate the description of the people who hold power in 
Canadian society such as CEOs of large corporation, judges, members of parliament and place these descriptors on one of the layers of the flower. Then students fill in their own social identity on another layer. Again, depending on the class, we may discuss how their identities are similar and different from those who hold power and what are the implications of these similarities and differences. Another question might be how do various aspects of their identity intersect to either reinforce or undercut whatever privilege might be accorded to them within Canadian society. The power flower then becomes the basis for the teacher candidates to write a brief personal description of their own social identities. Ideally, this is not just a list based on various categories of identity but a description of how their perceived identities in these categories affected the teacher candidates and how they grappled with these impacts, including any complex or contradictory aspects of how their social identities are enacted.

An Indo-Canadian man wrote about how the two most apparent and pressing aspects of his identity were gender and race. While he acknowledged that gender gave him privilege especially since he was a heterosexual man "living in a predominantly heteronormative and patriarchal society," he felt that gender was not a primary identity factor for him because he had never ascribed to the traits usually connected to "hyper-masculinity." He went on to describe why race was so integral to his social identity:

"Being an Indo-Canadian is critical to my social identity only because its what I am primarily seen as and judged upon. I cherish and value my Indian heritage and make a concerted effort to speak the language and maintain my ability to read and write Punjabi. However, it's not what I want to be perceived as. By that I mean I don't want to be reduced to the colour of my skin and the country where my family originated. I hear statements that I am "not looking brown," "not listening to brown music," you're whitewashed" and you are "too brown" or not "brown enough." These statements are troublesome because I'm being told by a third party that I meet, exceed or fail to fulfill the requirements of a societal expectation based solely on my race. And this goes beyond other people's stereotypes. Even people in my family tell me that I should do more/less of "X" because I am Indian; what does that even mean?"

This teacher candidate's insistence on the importance of his heritage to his sense of identity but his resentment of the expectations of him by friends and family members based on this heritage are very reminiscent of the young people in Dan Yon's study. The difference is perhaps that as an adult this teacher candidate can hold this complexity without turning away from his heritage. In his final paper, a critical analysis of his teaching practicum, this teacher candidate talked about his connection with a South Asian male student who was clearly capable but was not doing well at school, in part because of his drug use. The teacher candidate talks about how this boy reminded him of himself at that age. He also discusses his attempts to counteract the negative stereotypes other teachers had of this student and near the end of the teaching practicum tries to give him advice, "without telling him what to think or do" about how his attitude to school would ultimately be a disservice to his own future. The teacher candidate referred to his exchange with his student as "probably the biggest teaching moment of my practicum."

Not surprisingly, many of the teacher candidates in this class who were racialized mentioned race as an important factor in their social identities. For example, a Black male teacher candidate in describing how he tries to counter racist stereotypes of Black people wrote:

"I may say something like 'I'm black but I don't have a record' or 'I'm a post-secondary graduate.' I would include anything atypical of the black stereotype. It has not occurred to me that I may have been perpetuating the negative stereotypes that I have been trying to avoid...Quite unfortunately, race matters because society has made it matter."

This teacher candidate also commented in class on how he always strives to speak well (English and Politics were his two teaching subjects), to be gentle and to dress in a "non black' way. He also identified that he comes from a single parent family and grew up in a poor neighbourhood where there was a lot of crime. He was very engaged by our work on stereotype threat through the reading of sections from Claude Steele's Whistling Vivaldi. He was particularly struck by the story that Steele tells 
that provides the title for his book on stereotype threat [6]. An African American man tells the story about his experience as a psychology graduate student at the University of Chicago. He becomes aware that his very presence is seen as threatening by the pedestrians in the upscale neighbourhood of the campus. Not wanting to instill fear, he decides to whistle and chooses popular tunes from the Beatles and Vivaldi's Four Seasons. He immediately notices the difference in the demeanour of other pedestrians. I think that my teacher candidate shared this African American man's desire to distinguish himself from the stereotypes that Canadians might have of a Black man and was delighted to see his own desires around counteracting negative stereotypes of Black men addressed in a scholarly text. It is interesting to me that in his analysis of his practicum this teacher candidate discusses a Black boy who seems to feel a connection to him and even mentions to another teacher that this Black teacher candidate is the only teacher who "gets him." Other teachers saw the Black student as unruly and not particularly interested in school. The teacher candidate goes on to say:

"The only similarities that we shared were that I was a man, and I was Black. How selfaware must he be to identify with me based on my race? Was that why he thought I understood him? I know nothing about him besides the teacher gossip and what little he shared with me. And yet, he was the most receptive with me of all his teachers. I'm apprehensive to say that it is due to our shared racial identity because that was not the same experience for myself when I was a student and had a Black teacher."

The teacher candidate is not sure what to make of this student's sense of connection with him. The teacher candidate's reluctance to believe that this is based on a shared racial identity is influenced by his own experience with a Black teacher but I believe also by his own discomfort with racial stereotypes and his felt need to distance himself from these stereotypes. Despite the fact that he shared other aspects of identity with this boy, who is being raised by a hard-working single mother, the teacher candidate continues to resist the connection made by the student.
"Yes, I am Black, but no, I don't get him. There are just too many factors at play for me to be sure that my blackness tamed the ill-behavior that he's supposedly prone to exhibit. And yet, because he believes I get him, that alone gives me an edge in shaping his behavior. If my being Black affects that, then I suppose it is a resource that I'll have to be aware of. Oddly enough, this is the first time I've considered my racial identity as having a single positive attribute."

The teacher candidate is rejecting a simplistic analysis of the student's sense of connection with him and that seems very positive but I believe that his words also indicate his struggle to see his identity as a potential connection with this particular student who seemed to enact the negative stereotypes often associated with Black students and from which this teacher candidate wants to distance himself. Elsewhere in the course, this teacher candidate grappled with ethical considerations about treating students differently based on their identities. $\mathrm{He}$ acknowledged that not all students arrived at school with the same opportunities. Ultimately he hopes that he will be able to "create a space that makes it easier for minority students to learn as efficiently as white students."

A Chinese Canadian woman who was very sophisticated in her analysis of equity issues in education described her identity as follows:

"I am a fair-skinned Chinese woman who is not able to speak any Chinese nor understand anything beyond basic words. However, despite not having a linguistic stake in the Chinese community, I make friends easily with people who share my cultural background. I usually feel embarrassment when I am found to be only among Chinese people as I do not want to be 'seen' as racist and I take pride in having nonAsian, non light skinned friends. I realize as well that even within the Chinese community, we also hold negative racialized views against gradients of skin colour since in older times, peasants that worked the field were darker whereas emperors stayed indoors and so were lighter skinned. I apply sunblock every day even in the winter and I don't know whether I can justify this 'internalized antiquated prejudice' based on the fact that I want to prevent the development of skin cancer." 
I can imagine this woman smiling wryly as she writes these words. She has a keen understanding of the racist (and class biased) nature of attitudes around skin color within her own community but is well able to see that though she can analyze these attitudes she has also internalized them.

Another racialized woman in the class described her social identity as follows:

"When I walk out my front door as a first generation, Tamil-Canadian woman, I am aware that the identity I leave with, the one that I have defined for myself with the influence of my family and community, will undergo construction through people's perception of me. As a first generation Canadian there is greater pressure to make use of my opportunities and create a life here, yet simultaneously, the status leaves some questioning the 'authenticity' of my Canadian identity and the right to claim a life here. My hyphenated identity as a TamilCanadian allows me to bridge both cultures together, but sometimes the sequence is questioned for what is perceived as the prioritization of one over the other. It is through my gender that I have become most aware of how context can change the impact of social identity. At home, my family has always encouraged me to be an independent woman, but I find that I am still aware of the stereotypes and limitations placed on women because of how often I see it unfold in society. When I walk back in through my front door, I am aware that the perceptions made about me today will influence how I define my social identity tomorrow, and so my social identity is always in the midst of construction."

Interestingly, this teacher candidate's racial identity was most prominent for her in one of her experiences from the practice teaching. Due to the need for more supervisors to observe teacher candidates in their practicum, the institution hired several retired teachers and administrators. A white man who had been a principal but had extensive teaching experience in her subject area observed this particular teacher candidate teaching. She described him as being very cordial and friendly. After observing her lesson, he mentioned that he had been a principal in an area of the city where there were a number of Tamil students. He went on to say that he hoped that this was not offensive but that he was surprised by how much confidence she displayed for a Tamil woman. When she asked what he meant he continued by talking about how the women are generally not confident because of "what happens in their homes." She was baffled and shocked by his comments but did not challenge this man; however, she did complain to the relevant supervisory staff at OISE/UT.

She shared this information in our first class after the practicum and explained that she did not think that this man was a "bad person" but that his behaviour was to her a clear example of white privilege. To him the norm for the expression of confidence was white people and he expressed surprise when he encountered similar confidence in a Tamil woman. Several people in the class including other racialized teacher candidates expressed the opinion that this was not an example of white privilege but of simple ignorance. Others expressed concern about her complaint to the institution and the possible repercussions this would have on this man. In the midst of this discussion another teacher candidate who self identified as a Filipino woman shared that she had been observed by this same man in another school and that he had told her after his observations that she had a "white girl's voice." Several questions were asked about what he might have meant by this and the teacher candidate said that based on his further comments, he was referring to the confidence with which she spoke in the classroom. This story escalated the discussion and there was at times more heat than light in what was being said. Then something quite amazing happened. A white female teacher candidate checked in with the first teacher candidate who had shared her story about this man and realized that he was the same person who had observed her teaching. She then told the class that in his comments on her teaching he made no references to any aspect of her identity. Prior to the practicum this woman and a few other women in the class, who were not very tall and who looked younger than they were, expressed concern about how these factors might work against them in the classroom because they felt that they would not be taken seriously.

The white man who did the observations in these three cases gave the white woman extensive feedback on the content of her lesson and on her teaching strategies with absolutely no 
references to her race, her gender or her physical appearance. The white female teacher candidate said that she was sharing this experience because it confirmed what the first teacher candidate had claimed. To all three women and to me this was clearly a case of white privilege in operation.

After the class the white teacher candidate and the Tamil Canadian teacher candidate stayed behind to chat. The Tamil Canadian appreciated the fact that the white woman had spoken up but was concerned that for some people the voice of a white person speaking about white privilege might have carried more weight. Both teacher candidates were concerned that several of their colleagues did not see this as an example of white privilege and were more concerned for the man than for the people whom he was observing.

\section{Conclusion}

Teaching this course is always a true learning experience for me. I believe that supporting new teachers to be aware of their social identity and how it might influence their teaching is important work. At the same time, the concepts with which we are dealing are "messy" and slippery. I do feel that I bring extensive background knowledge of social justice and equity issues in education to my work with the teacher candidates. However, their insights, responses, and resistances to our work together continually help me to explore questions to which I do not have solid or final answers. The dynamic of each class is of course different depending on the particular composition of the group, the time in their development as teachers that the course takes place, and so many unknown factors. Still I find myself, as I think most teachers do, considering how I can learn from my experience with this group to improve the learning space for the next group that I will teach.

\section{References}

[1] John Dewey, How we think: A restatement of the relation of reflective thinking to the educative process, Heath \& Co, Boston, 1933.

[2] Dan Yon, Elusive Culture: Schooling, Race, and Identity in Global Times. Albany: State University of New York Press, 2000.
[3] Nel Noddings, The Challenge to Care in Schools: An Alternative Approach to Education, 2nd Ed, New York, Teachers College Press, 2005.

[4] Özlem Sensoy and Robin DiAngelo, Is Everyone Really Equal? An Introduction to Key Concepts in Social Justice Education. New York and London: Teachers College, Columbia University, 2012.

[5] This is Barb Thomas' adapted version of Enid Lee's original Flower Exercise from Letters to Marcia: A Teacher's Guide to Anti-Racist Education, Toronto, Cross-Cultural Communication Centre, 1985.

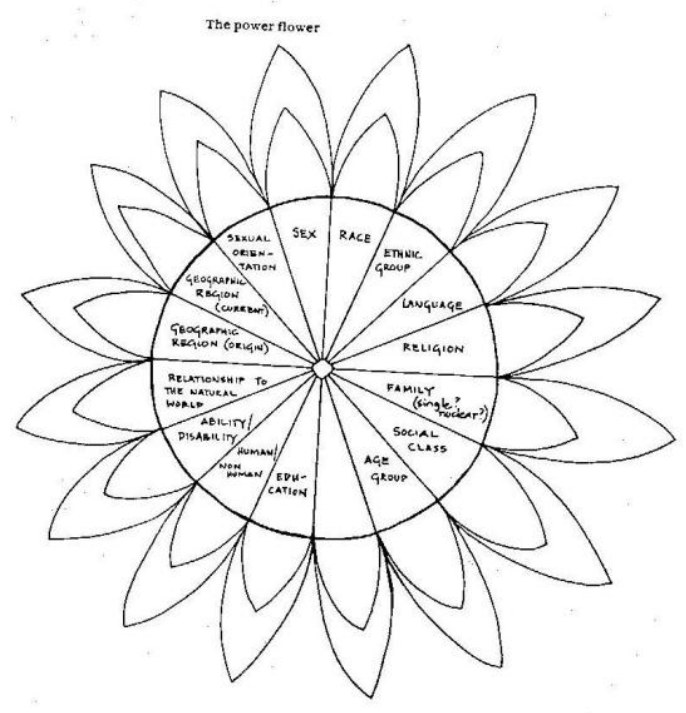

[6] Claude M. Steele, Whistling Vivaldi: How Stereotypes Affect Us and What We Can Do, New York, W.W. Norton and Company, Inc., 2011. 